\title{
Comparison of organic matter oxidation approaches in sediment diagenesis models
}

\author{
$\underline{\text { D. Paraska }}^{\text {a }}$, M. R. Hipsey ${ }^{\text {a }}$, and S. U. Salmon ${ }^{\text {a }}$ \\ ${ }^{a}$ School of Earth and Environment, The University of Western Australia, 35 Stirling Hwy, Crawley, Western \\ Australia, 6009
}

\section{Email:parasd02@student.uwa.edu.au}

\begin{abstract}
Sediment diagenesis models have been developed over the past few decades using various algorithms and notation for similar processes. Organic matter oxidation in particular has been parameterised in a number of different ways. The reactions involved are the sequence of decreasing energy-yield oxidation pathways (aerobic mineralisation, denitrification, $\mathrm{Mn}(\mathrm{IV})$ reduction, $\mathrm{Fe}(\mathrm{III})$ reduction, $\mathrm{SO}_{4}{ }^{2-}$ reduction and methanogenesis). In this paper we examine the differences between three common approaches that have emerged in the literature and quantify whether the differences have a significant effect on organic matter oxidation rates.
\end{abstract}

Firstly, the equations of three approaches were expressed using a common notation, highlighting the similarities and differences between the rate expressions. All approaches have an oxidation rate that is the product of the rate constant $k_{O M}$, organic matter concentration OM, a limitation term $\Theta_{O x}$, and an inhibition term $\Theta_{I n}$. The $\Theta_{O x}$ and $\Theta_{I n}$ of Approach 1 apply Monod kinetics. The $\Theta_{O x}$ and $\Theta_{I n}$ of Approach 2 apply Blackman kinetics, which has previously been described as not significantly different to a Monod formulation. Approach 3 uses Monod terms while mixing the limitation and inhibition functions differently to Approach 1. While Approaches 1 and 2 usually use six oxidation pathways, Approach 3 uses three pathways, combining manganese, iron and sulfate reduction and methanogenesis into one anoxic pathway. Methanogenesis in Approach 1 is a product of the previous five inhibition terms, whereas in Approach 2 it is the difference between the total rate and the sum of the five higher-energy rates.

The algorithms of the three approaches were compared with a simple calculation of organic matter oxidation on a homogenous unit of sediment over 3 years, in marine and freshwater conditions. The differences between the approaches were illustrated in terms of the points in time when the oxidants are exhausted. In all

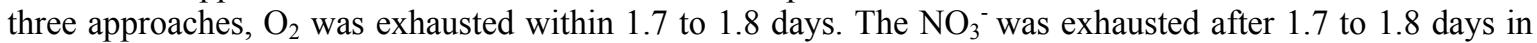
Approaches 2 and 3, but after 2.8 days in Approach 1. In Approach $1 \mathrm{Mn}(\mathrm{IV})$ was exhausted at day 798 and $\mathrm{Fe}(\mathrm{III})$ at day 857, whereas these components were not exhausted in Approach 2 in the three year simulation, and not simulated in Approach 3. In the freshwater experiment, $\mathrm{SO}_{4}{ }^{2-}$ was depleted by days 425 and 215, respectively. While the time to depletion differed considerably, it is of note that both approaches allowed depletion of $\mathrm{SO}_{4}{ }^{2-}$ prior to the more thermodynamically favourable oxidants.

Approaches 1 and 3 allow for more overlap of the rates of different oxidation pathways whereas Approach 2 only allows for overlap when the oxidant concentration is below its limiting concentration. This represents a different conceptualisation of the microbial processes in the sediment with bacteria either partially or completely inhibited. Implications of this include that at the time when the corresponding reduction pathway began in Approach 2, in Approach $125 \%$ of $\mathrm{NO}_{3}{ }^{-}, 17 \%$ of $\mathrm{Fe}(\mathrm{III})$ and $1 \%$ (marine experiment) or $38 \%$ (freshwater experiment) of $\mathrm{SO}_{4}{ }^{2-}$ had already been consumed.

Approaches 1 and 2 exhibited a steady decline in total organic matter oxidation rate as organic matter concentration decreases, whereas in Approach 3 there was an increase in the total rate when denitrification and anoxic processes overlapped due to the lack of inhibition of anoxic processes.

The differences between the approaches are significant enough to suggest that care must be taken in choosing which best represents the modeller's conceptualisation of microbial processes. The effects of secondary reactions and transport processes between sediment layers on the chemical profiles will be tested in future work using a full diagenesis model.

Keywords: Sediment, diagenesis, reactive transport model, organic matter 


\section{INTRODUCTION}

Biogeochemical reactions in aquatic sediment can affect the amount of dissolved $\mathrm{O}_{2}$ in the overlying water and the adsorption or release of contaminants and nutrients. Examples of processes that may be involved include burial of nutrients in the sediment or cycling back to the water column, denitrification, depletion of dissolved $\mathrm{O}_{2}$ available to aquatic organisms, dissolution and reduction of solid $\mathrm{Mn}(\mathrm{IV})$ and $\mathrm{Fe}(\mathrm{III})$ and the subsequent release of any nutrients or contaminants adsorbed to their surfaces, generation of $\mathrm{H}_{2} \mathrm{~S}$ gas or metal sulphides, and generation of $\mathrm{CH}_{4}$ gas. Numerical models of sediment physical-biogeochemical processes (collectively termed 'early diagenesis') have been developed and applied to unravel the effects of the many competing and interdependent reactions (Boudreau, 1997).

While the models that have been developed over the past few decades started with a common origin (Berner, 1964; Berner, 1980), they have since diverged into several model 'families' that have a similar underlying basis but different algorithms, variables, notation, and parameter values. However, there is limited analysis comparing the differences between the approaches. The focus of this analysis is how three common modelling approaches treat the oxidation of organic matter $(\mathrm{OM})$, as this process governs sediment function and quality. These models all describe OM degradation by a sequence of bacterially-driven reactions with decreasing free energy yield, as described by Froelich et al. (1979). The reactions used are taken from Van Cappellen and Wang (1996):

$$
\begin{gathered}
\mathrm{OM}+130 \mathrm{O}_{2}+14 \mathrm{HCO}_{3}^{-} \stackrel{R_{O_{2}}}{\longrightarrow} 118 \mathrm{CO}_{2}+12 \mathrm{NO}_{3}^{-}+\mathrm{HPO}_{4}^{2-}+132 \mathrm{H}_{2} \mathrm{O} \\
\mathrm{OM}+92 \mathrm{NO}_{3}^{-} \stackrel{R_{N O}}{\longrightarrow} 52 \mathrm{~N}_{2}+16 \mathrm{CO}_{2}++90 \mathrm{HCO}_{3}^{-}+\mathrm{HPO}_{4}^{2-}+80 \mathrm{H}_{2} \mathrm{O} \\
\mathrm{OM}+212 \mathrm{MnO}_{2}+328 \mathrm{CO}_{2}+116 \mathrm{H}_{2} \mathrm{O} \stackrel{R_{M n}}{\longrightarrow} 212 \mathrm{Mn}(\mathrm{II})+434 \mathrm{HCO}_{3}^{-}+12 \mathrm{NH}_{4}{ }^{+}+\mathrm{HPO}_{4}^{2-} \\
\mathrm{OM}+424 \mathrm{Fe}(\mathrm{OH})_{3}+752 \mathrm{CO}_{2} \stackrel{R_{F e}}{\longrightarrow} 424 \mathrm{Fe}^{2+}+858 \mathrm{HCO}_{3}^{-}+12 \mathrm{NH}_{4}{ }^{+}+\mathrm{HPO}_{4}^{2-}+308 \mathrm{H}_{2} \mathrm{O} \\
\mathrm{OM}+53 \mathrm{SO}_{4}{ }^{2-}+10 \mathrm{CO}_{2}+10 \mathrm{H}_{2} \mathrm{O} \stackrel{R_{S O} \mathrm{O}_{4}}{\longrightarrow}+53 \mathrm{H}_{2} \mathrm{~S}+116 \mathrm{HCO}_{3}^{-}+12 \mathrm{NH}_{4}{ }^{+}+\mathrm{HPO}_{4}^{2-}+106 \mathrm{H}_{2} \mathrm{O} \\
\mathrm{OM}+10 \mathrm{H}_{2} \mathrm{O} \stackrel{R_{M e t h}}{\longrightarrow} 53 \mathrm{CH}_{4}+43 \mathrm{CO}_{2}+12 \mathrm{NH}_{4}{ }^{+}+\mathrm{HPO}_{4}^{2-}
\end{gathered}
$$

where $\mathrm{OM}=\left(\mathrm{CH}_{2} \mathrm{O}\right)_{106}\left(\mathrm{NH}_{3}\right)_{12} \mathrm{HPO}_{4}$, although stoichiometry differs between modelling studies. The models examined here follow Berner's principle of calculating the oxidation of organic matter as a function of OM concentration and usually independent of oxidant concentration while the concentration is high. When the oxidant is reduced to limiting concentrations, a limitation effect is included (Berner, 1964). In addition, reactions with oxidants resulting in a higher free energy yield are assumed to occur in preference to those involving oxidants with lower free energy yield. For example, aerobic bacteria will consume $\mathrm{OM}$ until the $\mathrm{O}_{2}$ is consumed, after which the denitrifying bacteria will be able to oxidise $\mathrm{OM}$ at the maximum rate (Megonigal et al., 2003). The models take this process into account by including an inhibition factor in the rate laws.

The models that have been developed adopt different algorithms to represent these chemical and microbial processes (OM dependence, limitation and inhibition) mathematically, while attempting to strike their own balance between simplicity and complexity. The aim of this study was to analyse and compare three common approaches and identify similarities and differences between them. We firstly present the rate laws in equivalent notation to highlight differences and similarities, and secondly we quantitatively assess the differences between the approaches when applied to two hypothetical sediment conditions, representing marine and fresh water.

\section{MODEL APPROACHES}

Approach 1 originally stems from Boudreau (1996), Approach 2 from Van Cappellen and Wang (1996) and Approach 3 from Soetaert et al. (1996a; 1996b). The total OM reaction rate $\left(\mathrm{R}_{\mathrm{OM}}\right)$ is the sum of oxidation pathways (1) to (6) in Approaches 1 and 2 (from Van Cappellen and Wang, 1996), and pathways (1), (2) and (7) in Approach 3, where equation (7) combines several anoxic processes.

$$
\mathrm{OM}+\mathrm{An} \text { oxidant } \stackrel{\mathrm{R}_{\text {Anox }}}{\longrightarrow} 106 \mathrm{ODU}+106 \mathrm{CO}_{2}+12 \mathrm{NO}_{3}^{-}+\mathrm{HPO}_{4}^{2-}+106 \mathrm{H}_{2} \mathrm{O}
$$

Oxygen demand units (ODU) in Eq.7 are a combination of reduced-species products of anoxic oxidation that could be oxidised by other processes. The governing rate laws have been expressed in Table 1 . 
Paraska et al., Comparison of organic matter oxidation approaches in sediment diagenesis models

Table 1 Summary of the three main approaches to OM oxidation equations

\begin{tabular}{|c|c|c|c|}
\hline $\begin{array}{l}R_{O M} \text { Total OM oxidation } \\
\text { rate }\end{array}$ & $\begin{array}{l}\text { Oxidation rate due to } \\
i^{\text {th }} \text { oxidant } R_{O x_{i}}\end{array}$ & Oxidation term $\Theta_{o x_{i}}$ & $\begin{array}{l}\text { Inhibition term } \Theta_{I n_{i}} \\
\Theta_{I n_{1}}=1\end{array}$ \\
\hline $\begin{array}{l}\text { Approach } 1 \\
i \text { from reactions } 1 \text { to } 6 \\
\qquad R_{O M}=\sum_{i=1}^{6} R_{O x_{i}}\end{array}$ & $\begin{array}{l}R_{O x_{i}} \\
=k_{O M} O M \Theta_{O x_{i}} \Theta_{I n_{i}}\end{array}$ & for $i=1$ to $5, \Theta_{O x_{i}}=\left(\frac{O x_{i}}{K_{O x_{i}}+O x_{i}}\right), \Theta_{O x_{6}}=1$ & $\begin{array}{l}\text { for } i=2 \text { to } 6, \Theta_{I n_{i}}= \\
\prod_{j=1}^{i-1}\left(\frac{K_{O x_{j}}}{O x_{j}+K_{O x_{j}}}\right)\end{array}$ \\
\hline 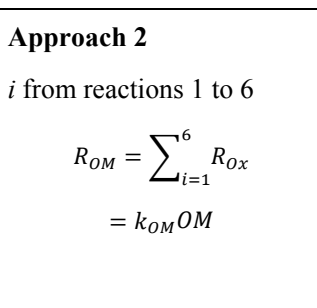 & $\begin{array}{l}\text { for } i=1 \text { to } 5 \\
R_{O x_{i}} \\
=k_{O M} O M \Theta_{O x_{i}} \Theta_{I n_{i}} \\
\quad \text { and } \\
R_{O x_{6}} \\
=k_{O M} O M-\sum_{i=1}^{5} R_{O x_{i}}\end{array}$ & $\begin{array}{l}\text { for } i=1 \text { to } 5 \\
\Theta_{O x_{i}=}=\left\{\begin{array}{cc}0 & \text { when } O x_{i-1}>L_{O x_{i-1}} \\
1 & \text { when } O x_{i-1}<L_{O x_{i-1}} \text { and } O x_{i}>L_{O x_{i}} \\
\frac{O x_{i}}{L_{O x_{i}}} & \text { when } O x_{i-1}<L_{O x_{i-1}} \text { and } O x_{i}<L_{O x_{i}}\end{array}\right. \\
\Theta_{O x_{6}}=1\end{array}$ & $\begin{array}{l}\text { for } i=2 \text { to } 5 \\
\quad \Theta_{I n_{i}} \\
=\prod_{j=1}^{i-1}\left(1-\frac{O x_{j}}{L_{O x_{j}}}\right)\end{array}$ \\
\hline $\begin{array}{l}\text { Approach } 3 \\
i \text { from reactions } 1,2 \text { and } 7\end{array}$ & $\begin{array}{l}R_{O x_{i}} \\
=k_{O M} O M \Theta_{O x_{i}} \Theta_{I n_{i}}\end{array}$ & $\begin{array}{c}\text { for } i=1,2, \Theta_{O x_{i}}= \\
\left\{\begin{array}{c}\left(\frac{O x_{i}}{K_{O x_{i}}+O x_{i}}\right) \\
\left\{\begin{array}{c}O_{2} \\
K_{O_{2}}+O_{2}\end{array}\right)+\left(\frac{N O_{3}}{K_{N O_{3}}+N O_{3}}\right)\left(\frac{K_{O_{2}}^{N O_{3}}}{O_{2}+K_{O_{2}}^{N O_{3}}}\right) \\
+\left(\frac{K_{N O_{3}}^{A n o x}}{N O_{3}+K_{N O_{3}}^{A n o x}}\right)\left(\frac{K_{O_{2}}^{A n o x}}{O_{2}+K_{O_{2}}^{\text {Anox }}}\right)\end{array}\right\} \\
\text { for } i=3,\left(\frac{O x_{i}}{K_{O x_{i}}+O x_{i}}\right)=1\end{array}$ & $\begin{aligned} & =\prod_{j=1}^{\Theta_{I n_{i}}}\left(\frac{K_{I n_{j}}}{O x_{j}+K_{O x_{j}}}\right) \\
= & \prod_{j=1}^{i-1}\left(1-\frac{O x_{j}}{O x_{j}+K_{I n_{j}}}\right)\end{aligned}$ \\
\hline Approach 1 & \multicolumn{3}{|c|}{$\begin{array}{l}\text { Boudreau 1996, Boudreau 1998, Luff et al. 2000, Haeckel et al. 2001, Koenig et al. 2001, Wijsman et al. 2002, } \\
\text { Meysman 2003, Luff and Moll 2004, Katsev et al. 2006, Devallois et al. 2008, Dittrich et al. 2009, Massoudieh et al. } \\
2010\end{array}$} \\
\hline Approach 2 & \multicolumn{3}{|c|}{$\begin{array}{l}\text { Van Cappellen and Wang 1996, Hunter et al. 1998, Berg et al. 2003, Fossing et al. 2004, Canavan et al. 2006, } \\
\text { Sochaczewski et al. 2008, Kasih et al. 2008, 2009, Dale et al. } 2009\end{array}$} \\
\hline Approach 3 & \multicolumn{3}{|c|}{$\begin{array}{l}\text { Soetaert et al. 1996a, b, Middelburg et al. 1996, Soetaert 1998, Epping 2002, Sohma et al. 2008, Berg et al. 2007, } \\
\text { Hochard et al. } 2010\end{array}$} \\
\hline
\end{tabular}

A common feature of all three approaches is that the oxidation expression $R_{O x}$ is a product of four terms: an OM reaction rate constant $k_{O M}$; the OM concentration; a term $\Theta_{O x}$ for limitation; and an inhibition term $\Theta_{I n}$. In Approach 2 the sum of the individual oxidation pathway fractions always adds to 1 and $R_{O M}$ is always equal to $k_{O M} \mathrm{OM}$. This is achieved by setting the rate of methanogenesis, $R_{\text {Meth }}$ (the last OM breakdown pathway, equation (6)), to the difference between $k_{O M} \mathrm{OM}$ and the sum of the five higher-energy pathways. In contrast, in Approach $1, R_{\text {Meth }}$ has a separate rate expression (Table 1). However, as the concentrations of higher oxidants decrease towards zero, $\Theta_{O x}$ and $\Theta_{I n}$ tend towards 1 and therefore $R_{\text {Meth }}$ in Approach 1 also approaches $k_{O M} \mathrm{OM}$.

The $\Theta_{O x}$ term in Approach 1 is a Monod expression, which uses Monod half-saturation constants $(K)$, and which is chosen because it best reflects laboratory data of bacterially-controlled oxidation reactions (Boudreau and Westrich, 1984). The $\Theta_{O x}$ of Approach 3 consists of Monod functions, but also includes inhibition terms. In Approach 2 the $\Theta_{O x}$ is either 0,1 or the ratio of $O x_{i}$ to $L_{O x_{i}}$, depending on the oxidant concentration relative to $L_{O x_{i}}$, the specified limiting concentration.

The inhibition term $\Theta_{I n}$ in Approaches 1 and 3 is a Monod function, while in Approach 2 it is the 'modified Monod' term, which employs Blackman kinetics (Boudreau, 1997). Approach 3 has separate $K_{O x}$ and $K_{I n}$ values, whereas in the original references for Approaches 1 and 2 it is assumed that the equivalent of a $K_{I n}$ or $L_{I n}$ term would have the same value as $K_{O x}$ or $L_{O x}$. The value of the $L_{O x}$ in Approach 2 is a limiting concentration rather than a Monod half-saturation constant and therefore not directly comparable to the halfsaturation constants of Approaches 1 and 3, but it serves a similar purpose by limiting the reaction and inhibiting subsequent reactions. Approach 2 also adopts a discrete 'on/off' type formulation, where the rate is zero when the higher-energy oxidant concentration is above its $L_{O x}$. The 'modified Monod' term in Approach 
2 was chosen by Van Cappellen and Wang because it "increases computational efficiency and yields metabolic rate distributions that, for all practical purposes, are identical to those calculated with the full Monod law" (Van Cappellen and Wang, 1996). Whether these terms are in fact identical is a question that is investigated with the following experiments.

\section{MODEL APPLICATION}

For each of the three approaches, two simple numerical experiments were carried out where a homogenous unit of sediment was left to react in a closed system with a specified finite initial amount of each oxidant. In the second experiment the initial $\mathrm{SO}_{4}{ }^{2-}$ concentration was much lower, representing conditions of a freshwater lake, with $\mathrm{SO}_{4}{ }^{2-}$ concentrations and constants taken from (Katsev et al., 2006) and (Van Cappellen and Wang, 1995) for Approaches 1 and 2, respectively. All transport processes and other secondary chemical reactions were excluded. The initial concentrations of $\mathrm{OM}$ and oxidants in the first experiment were based on values in Boudreau (1996), Van Cappellen and Wang $(1995,1996)$ and Luff and Moll (2004), for typical coastal marine environments (Table 2). The $K_{O x}, K_{I n}, L_{O x}$, and $L_{I n}$ values were taken from Boudreau (1996), Van Cappellen and Wang (1996) and Soetaert et al. (1996) for Approaches 1, 2 and 3, respectively. The reactions (1) to (6) were used for Approaches 1 and 2 and reactions (1), (2) and (7) for Approach 3, with the stoichiometry from Van Cappellen and Wang (1996). The calculations were run for 3 years with an hourly time step using a first-order explicit finite difference.

Table 2 Initial conditions $(\mu \mathrm{M})$ and oxidation and inhibition constants

\begin{tabular}{|c|c|c|c|c|c|c|c|c|c|c|c|c|c|c|}
\hline \multirow{4}{*}{$\begin{array}{l}\text { A1 } \\
\text { Marine }\end{array}$} & \multicolumn{6}{|c|}{ Initial concentration $(\mu \mathrm{M})$} & \multicolumn{5}{|c|}{ Monod $K$ or limiting concentration $L$} & \multicolumn{3}{|c|}{$K_{I n}$ for Approach 3} \\
\hline & $\mathrm{O}_{2}$ & $\mathrm{NO}_{3}$ & $\mathrm{Mn}$ & $\mathrm{Fe}$ & $\mathrm{SO}_{4}$ & $\mathrm{OM}$ & $\mathrm{O}_{2}$ & $\mathrm{NO}_{3}$ & $\mathrm{Mn}$ & $\mathrm{Fe}$ & $\mathrm{SO}_{4}$ & $\mathrm{~K}_{\mathrm{O} 2}^{\mathrm{NO} 3}$ & $\mathrm{~K}_{\mathrm{O} 2}^{\mathrm{Anox}}$ & $\mathrm{K}_{\mathrm{NO3}}^{\mathrm{Anox}}$ \\
\hline & & & & & & & 8 & 30 & 10000 & 10000 & & - & - & - \\
\hline & 231 & 20 & 48000 & 50000 & 28000 & 500 & & & & & 1000 & & & \\
\hline Fresh & 231 & 20 & 48000 & 50000 & 100 & 500 & & & & & 400 & & & \\
\hline $\mathbf{A 2}$ & & & & & & & 20 & 5 & 24000 & 150000 & & - & - & - \\
\hline Marine & 231 & 20 & 48000 & 50000 & 28000 & 500 & & & & & 1600 & & & \\
\hline Fresh & 231 & 20 & 48000 & 50000 & 100 & 500 & & & & & 300 & & & \\
\hline $\mathbf{A 3}$ & & & & & & & 3 & 30 & - & - & - & 10 & 5 & 5 \\
\hline Marine & 231 & 20 & - & - & - & 500 & & & & & & & & \\
\hline Fresh & 231 & 20 & - & - & - & 500 & & & & & & & & \\
\hline
\end{tabular}

\section{RESULTS}

Changes in oxidant concentrations with time are shown in Figure 1. The total OM oxidation rates and contribution by different oxidation pathways are given in Figure 2. Oxidant exhaustion times, defined as when the oxidant reaches less than $1 \%$ of its initial concentration, are given in Table 4.

In Approach $1 R_{O 2}$ began as $96.7 \%$ of the total $R_{O M}, R_{N O 3} 1.3 \%$ and $R_{M n} 1.7 \%$ and there were very small contributions of the other three pathways. Approach 2 began with oxidation only by $\mathrm{O}_{2}$, as the inhibition term set the rates of the other pathways to zero. In Approach $3 R_{O 2}$ began as $96.1 \%$ of $R_{O M}, R_{N O 3}$ as $3.5 \%$ and $R_{A n o x}$ as $0.4 \%$.

Despite these differences, the exhaustion times of $\mathrm{O}_{2}$ were similar for all approaches (Table 3 ). The exhaustion times for $\mathrm{NO}_{3}{ }^{-}$were the same in Approaches 2 and 3 but one day later in Approach 1. Using the $K_{O x}$ and $K_{I n}$ values from Soetaert et al. (1996a; 1996b), in Approach 3 aerobic inhibition had a much stronger effect on subsequent reactions than that of $\mathrm{NO}_{3}{ }^{-}$inhibition on anaerobic processes. As a result, $\mathrm{R}_{\mathrm{OM}}$ exhibited an increase in the period after $\mathrm{O}_{2}$ was exhausted and before $\mathrm{NO}_{3}{ }^{-}$was exhausted (Figure 2), as denitrification and anoxic processes simultaneously oxidised the OM. With the "on/off" inhibition of Approach 2, the lower-energy oxidation pathways did not start until later and the overlap of pathways seen in Approaches 1 and 3 only occurred when the initial concentrations were below the limiting concentrations. The amounts of the oxidants remaining in Approach 1 at the equivalent start-time of an oxidation pathway in Approach 2 are given in Table 3. As an example, when oxidation by $\mathrm{NO}_{3}{ }^{-}$began in Approach 2 on day 1.5, 25\% of the $\mathrm{NO}_{3}{ }^{-}$ in Approach 1 was already consumed. Exhaustion times were similar between the marine and freshwater experiments, as expected given the similar configuration, except that $\mathrm{SO}_{4}{ }^{2-}$ reduction played a much smaller role and methanogenesis a much larger role in freshwater than in the marine experiment. $\mathrm{Mn}(\mathrm{IV})$ and $\mathrm{Fe}$ (III) were exhausted in Approach 1 but not within the simulation time in Approach 2, given the initial concentrations used here. In the marine experiment, $\mathrm{SO}_{4}{ }^{2-}$ was not exhausted; in the lake experiment, $\mathrm{SO}_{4}{ }^{2-}$ was exhausted 210 days later in Approach 1 than in Approach 2. Of note is that in both approaches where 
$\mathrm{SO}_{4}{ }^{2-}$ reduction is considered, $\mathrm{SO}_{4}{ }^{2-}$ was exhausted before $\mathrm{Mn}(\mathrm{IV})$ and $\mathrm{Fe}(\mathrm{III})$ in the freshwater experiments because of its much lower starting concentrations, despite the inhibition by higher-energy pathways which kept $R_{S O 4}$ low.
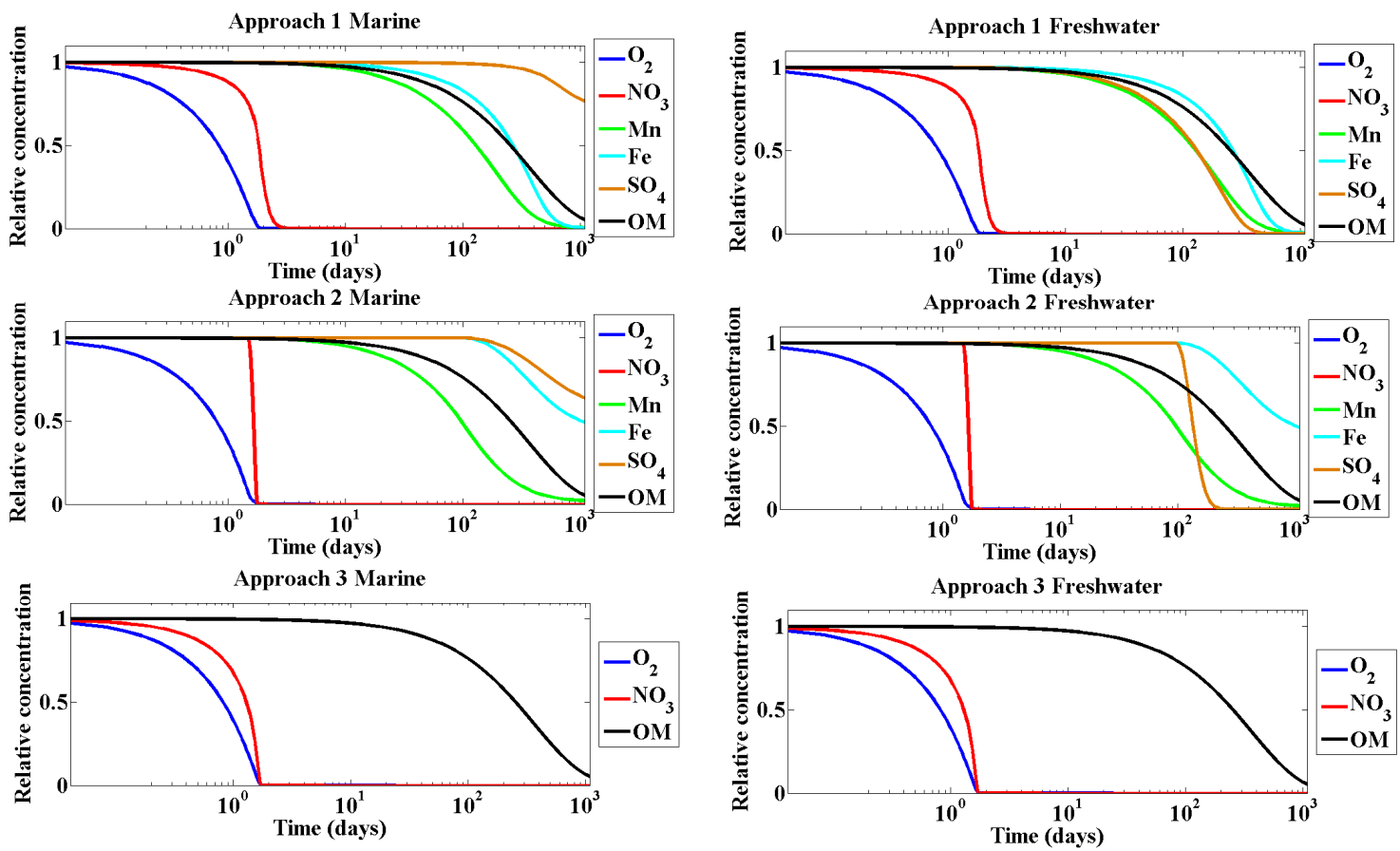

Figure 1 Changes in oxidant concentration with time relative to their initial concentrations.

Table 3 Oxidant in Approach 1 remaining at onset of oxidation pathway in Approach 2 $(N E=$ not exhausted $)$

Table 4 Oxidant exhaustion times (days)

\begin{tabular}{|c|c|c|c|c|c|c|c|c|c|c|c|}
\hline & $\mathrm{O}_{2}$ & $\mathrm{NO}_{3}^{-}$ & $\operatorname{Mn}(I V)$ & $\mathrm{Fe}(\mathrm{III})$ & $\mathrm{SO}_{4}{ }^{2-}$ & & $\mathbf{O}_{2}$ & $\mathrm{NO}_{3}^{-}$ & Mn(IV) & $\mathrm{Fe}(\mathrm{III})$ & $\mathrm{SO}_{4}{ }^{2-}$ \\
\hline $\begin{array}{l}\text { A1 } \\
\text { Marine }\end{array}$ & 1.83 & 2.79 & 797 & 857 & $N E$ & $\begin{array}{l}\text { A1 \% } \\
\text { remaining }\end{array}$ & 100 & 75 & 100 & 83 & 99 \\
\hline Fresh & 1.83 & 2.79 & 797 & 857 & 716 & Marine & 100 & 75 & 100 & 83 & 62 \\
\hline $\begin{array}{l}\text { A2 } \\
\text { Marine }\end{array}$ & 1.71 & 1.79 & $N E$ & $N E$ & $N E$ & Fresh & & & & & \\
\hline Fresh & 1.71 & 1.79 & $N E$ & $N E$ & $N E$ & $\begin{array}{l}\text { A2 } \\
\text { Start day }\end{array}$ & 1 & 1.5 & 1.75 & 96.1 & 96.1 \\
\hline $\begin{array}{l}\text { A3 } \\
\text { Marine }\end{array}$ & 1.71 & 1.71 & - & - & - & & & & & & \\
\hline Fresh & 1.71 & 1.71 & - & - & - & & & & & & \\
\hline
\end{tabular}

\section{DISCUSSION}

Despite the different approaches being built on similar conceptual models of sequential redox reactions, the choice of different kinetic expressions results in differences in sediment behaviour. Approach 1 allows all oxidation reactions to occur simultaneously, albeit with strong inhibition of the lower-energy oxidation pathways in the early stages. In Approach 2 the sediment allows for only one oxidation pathway to be active at any significant rate at a given time while the oxidant is above the equivalent $L_{O x}$. While Approach 3 is less informative in that it lumps $\mathrm{Mn}(\mathrm{IV}), \mathrm{Fe}(\mathrm{III})$ and $\mathrm{SO}_{4}{ }^{2-}$ reduction into a single anoxic process, its use of separate $K_{O x}$ and $K_{I n}$ gives it separate control of limitation and inhibition. However, despite the very different $K_{O x}$ values and limitation expressions in the three approaches, there were some surprising similarities, such as the initial reaction pathway profile in Approaches 1 and 3, and the $\mathrm{O}_{2}$ exhaustion times in all approaches. Also of interest was that in both the Approach 1 and 2 freshwater experiments, the expected sequential oxidant depletion of $\mathrm{Mn}(\mathrm{IV}), \mathrm{Fe}(\mathrm{III})$ and $\mathrm{SO}_{4}{ }^{2-}$ was not seen because initial concentrations of $\mathrm{Mn}(\mathrm{IV})$ and $\mathrm{Fe}(\mathrm{III})$ were high relative to $\mathrm{SO}_{4}{ }^{2-}$. However, in practice, secondary reactions such as reoxidation of $\mathrm{S}^{2-}$ to $\mathrm{SO}_{4}{ }^{2-}$ by $\mathrm{Fe}(\mathrm{III})$, would likely occur, leading to a higher apparent rate of $\mathrm{Fe}(\mathrm{II})$ reduction, and a longer apparent exhaustion time for $\mathrm{SO}_{4}{ }^{2-}$. Furthermore, the $\mathrm{Fe}$ and $\mathrm{Mn}$ in the sediments may be present in phases of varying lability (e.g. Berg et al., 2003). With these processes included in the model, the differences between 
the approaches could be amplified or suppressed. However, it is notable that the rate expressions for primary reactions in both approaches allow depletion of $\mathrm{SO}_{4}{ }^{2-}$ prior to more thermodynamically favourable oxidants.
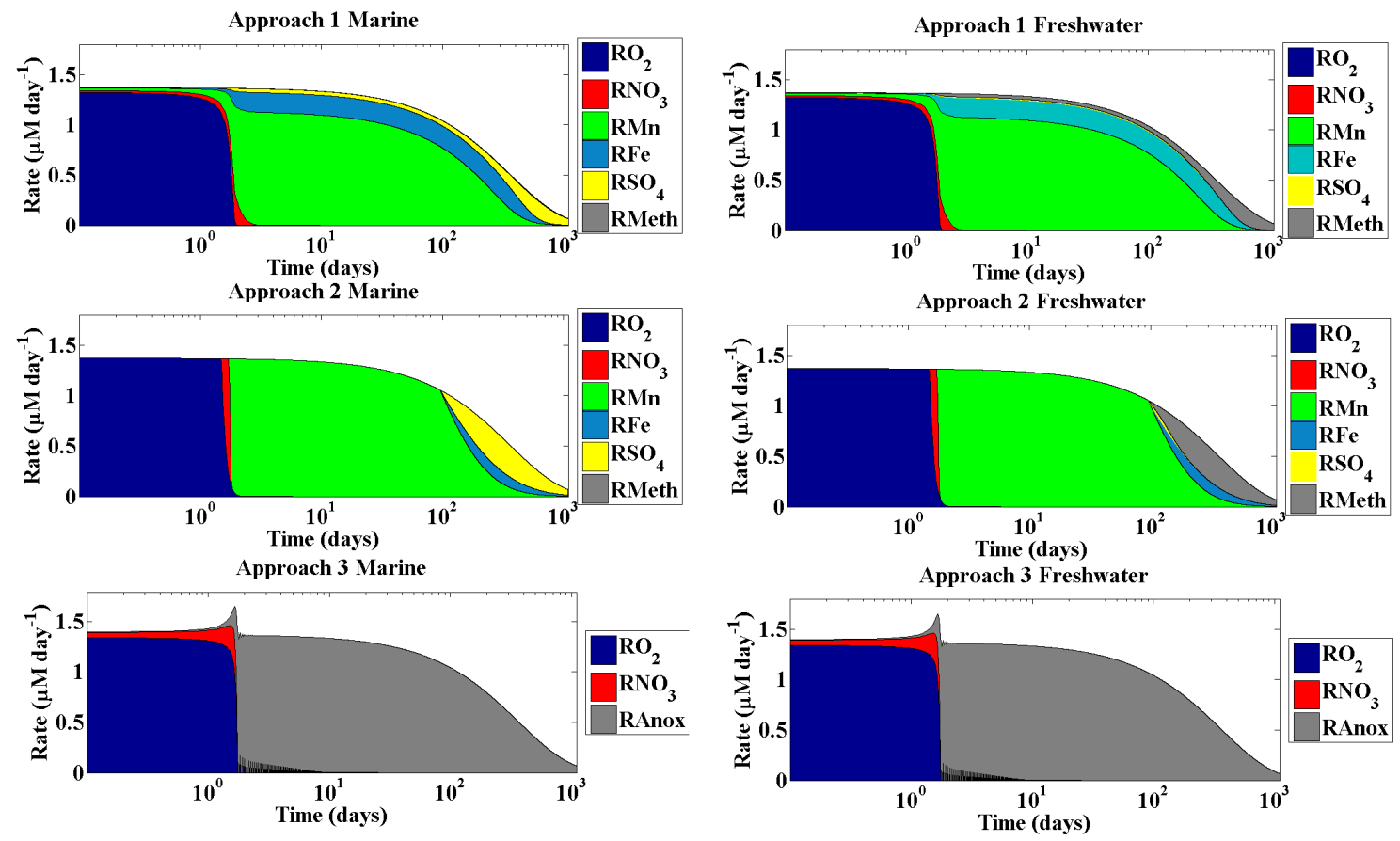

Figure 2 Total organic matter reaction rate and contribution of each oxidation pathway.

The temporal overlap of rates seen in Approach 1 creates a notable difference in the times at which oxidants are consumed compared to Approach 2. While quantities will depend on initial concentrations, in this example $38 \%$ of $\mathrm{SO}_{4}{ }^{2-}$ in Approach 1 was consumed before $\mathrm{SO}_{4}{ }^{2-}$ reduction commenced in Approach 2. In the case of $\mathrm{Fe}(\mathrm{III})$ reduction, a $17 \%$ difference in the generation of the reduced product $\mathrm{Fe}(\mathrm{II})$ over 96.1 days would lead to a considerable difference in the rate of diffusion of $\mathrm{Fe}(\mathrm{II})$ across sediment model layers.

When considering these OM oxidation reactions alone, the assumption that the Monod functions of Approaches 1 and 3 and Van Cappellen and Wang's "Modified Monod" are "identical" is not correct. The differences in the rate expressions resulted in different temporal evolution of oxidant concentrations in the different approaches. Whether these approaches are in fact "identical for practical purposes" will be determined in future work that will expand the experiment to a more complex diagenesis model able to account for additional processes as included in the original models, such as secondary chemical reactions and transport processes. Comparison of future laboratory experiments of OM oxidation by this series of oxidants may be able to show which approaches are the most appropriate for different environmental conditions.

\section{REFERENCES}

Anggara Kasih, G. A., S. Chiba, Y. Yamagata, Y. Shimizu and K. Haraguchi (2009). Numerical model on the material circulation for coastal sediment in Ago Bay, Japan. Journal of Marine Systems 77(1-2): 45-60.

Berg, P., S. Rysgaard and B. Thamdrup (2003). Dynamic modeling of early diagenesis and nutrient cycling. A case study in an Arctic marine sediment. American Journal of Science 303(10): 905-955.

Berner, R. (1964). An idealized model of dissolved sulfate distribution in recent sediments. Geochimica et Cosmochimica Acta 28(9): 1497-1503.

Berner, R. (1980). Early diagenesis: A theoretical approach. New Jersey, Princeton University Press.

Boudreau, B. (1997). Diagenetic models and their implementation. Heidelberg, Springer.

Boudreau, B., A. Mucci, B. Sundby, G. Luther and N. Silverberg (1998). Comparative diagenesis at three sites on the Canadian continental margin. Journal of Marine Research 56(6): 1259-1284.

Boudreau, B. and J. Westrich (1984). The dependence of bacterial sulfate reduction on sulfate concentration in marine sediments. Geochimica et Cosmochimica Acta 48(12): 2503-2516.

Boudreau, B. P. (1996). A method-of-lines code for carbon and nutrient diagenesis in aquatic sediments. Computers \& Geosciences 22(5): 479-496.

Canavan, R., C. Slomp, P. Jourabchi, P. Van Cappellen, A. Laverman and G. Van den Berg (2006). Organic matter mineralization in sediment of a coastal freshwater lake and response to salinization. Geochimica et Cosmochimica Acta 70(11): 2836-2855. 
Canavan, R. W., P. Van Cappellen, J. J. G. Zwolsman, G. A. van den Berg and C. P. Slomp (2007). Geochemistry of trace metals in a fresh water sediment: Field results and diagenetic modeling. Science of The Total Environment 381(1-3): 263-279.

Dale, A. W., V. Bruchert, M. Alperin and P. Regnier (2009). An integrated sulfur isotope model for Namibian shelf sediments. Geochimica et Cosmochimica Acta 73(7): 1924-1944.

Dittrich, M., B. Wehrli and P. Reichert (2009). Lake sediments during the transient eutrophication period: Reactive-transport model and identifiability study. Ecological Modelling 220(20): 2751-2769.

Epping, E., C. van der Zee, K. Soetaert and W. Helder (2002). On the oxidation and burial of organic carbon in sediments of the Iberian margin and Nazare Canyon (NE Atlantic). Progress in oceanography 52(2-4): $399-431$.

Fossing, H., P. Berg, B. Thamdrup, S. Rysgaard, H. Sorensen and K. Nielsen (2004). A model set-up for an oxygen and nutrient flux model for Aarhus Bay (Denmark).

Froelich, P., G. Klinkhammer, M. Bender, N. Luedtke, G. Heath and D. Cullen (1979). Early oxidation of organic matter in pelagic sediments of the eastern equatorial Atlantic suboxic diagenesis. Geochimica et Cosmochimica Acta 43(7): 1075-1090.

Haeckel, M., I. König, V. Riech, M. E. Weber and E. Suess (2001). Pore water profiles and numerical modelling of biogeochemical processes in Peru Basin deep-sea sediments. Deep Sea Research Part II: Topical Studies in Oceanography 48(17-18): 3713-3736.

Hochard, S., C. Pinazo, C. Grenz, J. L. B. Evans and O. Pringault (2010). Impact of microphytobenthos on the sediment biogeochemical cycles: A modeling approach. Ecological Modelling 221(13-14): 1687-1701.

Kasih, G. A. A., S. Chiba, Y. Yamagata, Y. Shimizu and K. Haraguchi (2008). Modeling early diagenesis of sediment in Ago Bay, Japan: A comparison of steady state and dynamic calculations. Ecological Modelling 215(1-3): 40-54.

Katsev, S., I. Tsandev, I. L'Heureux and D. G. Rancourt (2006). Factors controlling long-term phosphorus efflux from lake sediments: Exploratory reactive-transport modeling. Chemical Geology 234(1-2): 127147.

Koenig, I., M. Haeckel, A. Lougear, E. Suess and A. Trautwein (2001). A geochemical model of the Peru Basin deep-sea floor - and the response of the system to technical impacts. Deep-sea research. Part II, Topical studies in oceanography 48(17-18): 3737-3756.

Luff, R. and A. Moll (2004). Seasonal dynamics of the North Sea sediments using a three-dimensional coupled sediment-water model system. Continental Shelf Research 24(10): 1099-1127.

Luff, R., K. Wallmann, S. Grandel and M. Schluter (2000). Numerical modeling of benthic processes in the deep Arabian Sea. Deep-Sea Research Part Ii-Topical Studies in Oceanography 47(14): 3039-3072.

Massoudieh, A., F. A. Bombardelli and T. R. Ginn (2010). A biogeochemical model of contaminant fate and transport in river waters and sediments. Journal of Contaminant Hydrology 112(1-4): 103-117.

Megonigal, J. P., M. E. Hines and P. T. Visscher (2003). Anaerobic Metabolism: Linkages to Trace Gases and Aerobic Processes. Treatise on Geochemistry. D. H. Heinrich and K. T. Karl. Oxford, Pergamon: 317424.

Meysman, F. J. R., J. J. Middelburg, P. M. J. Herman and C. H. R. Heip (2003). Reactive transport in surface sediments. II. Media: an object-oriented problem-solving environment for early diagenesis. Computers \& Geosciences 29(3): 301-318.

Smith, S. and P. Jaffe (1998). Modeling the transport and reaction of trace metals in water-saturated soils and sediments. Water Resources Research 34(11): 3135-3147.

Sochaczewski, L., A. Stockdale, W. Davison, W. Tych and H. Zhang (2008). A three-dimensional reactive transport model for sediments, incorporating microniches. Environmental Chemistry 5(3): 218-225.

Soetaert, K., P. M. J. Herman and J. J. Middelburg (1996a). A model of early diagenetic processes from the shelf to abyssal depths. Geochimica et Cosmochimica Acta 60(6): 1019-1040.

Soetaert, K., P. M. J. Herman and J. J. Middelburg (1996b). Dynamic response of deep-sea sediments to seasonal variations: A model. Limnology and Oceanography 41(8): 1651-1668.

Van Cappellen, P. and F. Y. Wang (1995). Metal cycling in surface sediments. Metal contaminated aquatic sediments. H. Allen. Chelsea, Ann Arbor Press: 21 - 61.

Van Cappellen, P. and Y. F. Wang (1996). Cycling of iron and manganese in surface sediments: A general theory for the coupled transport and reaction of carbon, oxygen, nitrogen, sulfur, iron, and manganese. American Journal of Science 296(3): 197-243.

Van den Berg, G., J. Loch, L. van der Heijdt and J. Zwolsman (2000). Redox processes in recent sediments of the river Meuse, The Netherlands. Biogeochemistry 48(2): 217-235.

Wijsman, J., P. Herman, J. Middelburg and K. Soetaert (2002). A model for early diagenetic processes in sediments of the continental shelf of the Black Sea. Estuarine, Coastal and Shelf Science 54(3): 403-421 